\title{
Biochemical Assessment of the Relationship of Zinc and Glucose Concentration in Diabetics
}

\author{
Gborienemi Simeon George, Osagie Endely Friendgood \\ Department of Medical Laboratory Science, Niger Delta University, Wilberforce Island, Amassoma, Bayelsa State, Nigeria \\ Email: ozunugborie@gmail.com
}

How to cite this paper: George, G.S. and Friendgood, O.E. (2018) Biochemical Assessment of the Relationship of Zinc and Glucose Concentration in Diabetics. Open Journal of Endocrine and Metabolic Diseases, 8, 117-123.

https://doi.org/10.4236/ojemd.2018.84012

Received: February 10, 2018

Accepted: April 27, 2018

Published: April 30, 2018

Copyright $\odot 2018$ by authors and Scientific Research Publishing Inc. This work is licensed under the Creative Commons Attribution International License (CC BY 4.0).

http://creativecommons.org/licenses/by/4.0/

\begin{abstract}
Zinc plays a critical role in a variety of cell functions and elicits the fact that both its deficiency and excess may demonstrate deleterious situation. It has been proposed that zinc is required for multiple steps in insulin synthesis and release. This study investigated the relationship of zinc and glucose in diabetics. Using serum samples of diabetic patients whose glucose concentrations were above the threshold $(10.0 \mathrm{mmol} / \mathrm{l})$, spectroscopic methods were used to determine the concentration of glucose and zinc. Results obtained showed a negative correlation between level of glucose and zinc. Data were analyzed using student's t-test with the aid of Graph Pad Prism (R) version 6.01 with a $\mathrm{p}$ value of $<0.05$ considered statistically significant. We concluded that reduced concentration of zinc observed in the study could be an uncommon factor to hyperglycemia and impose risk factor to diabetics. Its evaluation along with glucose levels is highly recommended in management of diabetic patients.
\end{abstract}

\section{Keywords}

Biochemical, Relationship, Zinc, Glucose, Diabetics

\section{Introduction}

Zinc is an essential mineral with exceptional biological functions. It is required for normal cell processing such as cell division and apoptosis participating in multiple biochemical pathways such as transcription and cell division. Zinc is highly concentrated in the islet cells of the pancreas where insulin is produced. It is also vital in storage and secretion of insulin [1]. More than 300 enzymes need zinc to affect their catalytic activities. Jasen et al., [2] have confirmed that the removal of zinc from catalytic sites has resulted in loss of catalytic activity. In another study, [3] has shown that malabsorption of zinc results in various types 
of disorders including the dermal, gastrointestinal, neurological and immunological abnormalities. Recently published studies have revealed that type 2 diabetes patients have suboptimal zinc status in blood due to its increased urinary excretion [4]. Hypozincemia and hyperzincuria observed in diabetics have been elucidated by [5]. Zinc plays a key role in the storage and secretion of insulin which subsequently increases the uptake of glucose [6], and decreasing plasma level of zinc adversely affects the ability of islet cells to produce and secrete insulin [7]. Further works by [8] have established the fact that Zn transporter (ZnT8) is a key protein for the regulation of insulin secretion from pancreatic Beta-cells. Mutation in ZnT8 has been associated with type 2 diabetes. These facts give credence to the understanding that the importance of zinc in the maintenance and integration of insulin hexamer and its role in the metabolic regulation has a scientific proof.

The discovery of a variety of zinc related clinical disorders has directly demonstrated the importance of zinc in human nutrition. It is the second to iron as the most abundant trace element in the body [9] [10]. Zinc is widely distributed in food mainly bound to protein. The bioavailability of dietary zinc is dependent upon the digestion of these proteins to release zinc and allow it to bond to peptides, amino acids, phosphates and other ligands within the intestinal tract.

The relationship between diabetes, insulin and zinc is complex with no clear cause and effect relationship. In type 1 diabetes, there is a lack of insulin production, in type 2 diabetes, resistance of the effect of insulin is predominant. Both types have the same long-term complications. Diabetes is known to affect zinc homeostasis in variety of ways, although it is the hyperglycemia rather than any primary lesion related to diabetes, which is responsible for the increased urinary loss and decrease in total body zinc. The role of zinc deficiency which could at least potentially exacerbate the cytokinine-induced damage in autoimmune attack which destroys the islet cell in type 1 diabetes is still not clear. Since zinc plays a clear role in the synthesis, storage and secretion of insulin as well as conformational integrity of insulin in the hexameric form, the decreased zinc which affects the ability of the islets cells to produce and secret insulin might then compound the problem, particularly in type 2 diabetes where several of the complications may be related to increased intracellular oxidants and free radicals associated with decreases in intracellular zinc and in zinc dependent antioxidant enzymes. It has been shown that there appears to be a complex interrelationship between zinc and type 1 and 2 diabetes.

Insulin is stored as a hexamer containing two zinc ions in the Beta-cells of the pancreas and released into the portal venous system at the time of Beta-cells granulation [11]. In vitro and in vivo studies in animal and humans have shown that zinc has numerous beneficial effects in type 1 and 2 diabetes [12] [13] [14]. A recent meta-analysis confirmed these findings and concluded that zinc supplementation in patients with diabetes improves glycemic control and promotes healthy lipids parameters [15]. Other reviews as shown by [16] which comprehensively discuss zinc homeostasis in Beta-cells with emphasis on the potential 
signaling role of zinc in islet cells are available. This study seeks to investigate the underlying relationship between zinc, glucose and diabetes mellitus.

\section{Materials and Methods}

A total of one hundred (100) samples were collected from three tertiary hospitals in Yenagoa metropolis, Bayelsa State, Nigeria. The hospitals were Niger Delta University Teaching Hospital (NDUTH), Federal Medical Centre and Diete Koki Memorial Hospital. Subjects were both male and female diabetics $(n=100)$ with fasting glucose level above threshold $(10.0 \mathrm{mmol} / \mathrm{l})$ since the test was not designed for prediabetics. Another set of one hundred (100) samples were collected from non-diabetics with glucose levels ranging from $3.5-5.0 \mathrm{mmol} / \mathrm{l}$. Consent to permit collection of samples from patients were obtained at all the facilities. Samples were collected between $8.00 \mathrm{am}$ and $8.30 \mathrm{am}$ into fluoride oxalate bottle and plain containers for glucose and zinc respectively. The flouride oxalate prevents glycolysis. They were spun, separated to obtain plas$\mathrm{ma} / \mathrm{serum}$ respectively for the analysis.

Glucose was analysed by the enzymatic method Gluc-PAP (Randox) a product of Randox Laboratories Limited, UK. Glucose oxidase catalyses the oxidation of glucose to give hydrogen peroxide and gluconic acid. In the presence of the enzyme peroxidase, the hydrogen peroxide is broken down and the oxygen released reacts with 4-aminophenazone (4-amino antipyrene) and phenol to produce a pink colour that was measured at $540 \mathrm{~nm}$ with spectrophotometer $22 \mathrm{D}^{+}$ (Uniscope, England).

Serum zinc was analysed by direct atomic absorption spectrophotometer with the method of J.C. Smith, Jr. and G.P. Bitrimovi 1979 (USA) using Perkin Elmer 403 AAS. A calibration curve of standard zinc concentration was prepared and sample absorbance read off from the curve.

\section{Statistical Analysis}

Data collected from the subjects were analysed using students t-test with the aid of Graph Pad prism (R) software version 6.01 with $\mathrm{p}$ value set at $<0.05$ being considered as statistically significant.

\section{Result}

Results of the analysis are shown on Table 1 and Table 2. The mean standard deviation and standard error of mean for the diabetic and non-diabetic are

Table 1. Zinc concentration of diabetic patients and non-diabetics (control).

\begin{tabular}{ccccc}
\hline \multicolumn{5}{c}{ One-sample statistics } \\
\hline Diabetic zinc $(\mu \mathrm{g} / \mathrm{dL})$ & 100 & 65.22 & 8.01 & Std. error of mean \\
\hline Non-diabetic zinc $(\mu \mathrm{g} / \mathrm{dL})$ & 100 & 85.91 & 2.58 & 2.13 \\
\hline
\end{tabular}

$\mathrm{t}=44.291, \mathrm{P}=0.0001$. 
Table 2. Blood glucose concentration of diabetic patients and non-diabetics (control).

\begin{tabular}{ccccc}
\hline \multicolumn{5}{c}{ One-sample statistics } \\
\hline & $\mathrm{N}$ & Mean & Std deviation & Std. error of mean \\
\hline Diabetic glucose (mmol/L) & 100 & 11.06 & 2.97 & 0.42 \\
Non-diabetic glucose (mmol/L) & 100 & 4.74 & 1.56 & 0.22 \\
\hline
\end{tabular}

$\mathrm{t}=-13.12, \mathrm{P}=0.0001$.

shown with the total number evaluated. It can be deduced from the table that diabetics had decreased concentration of zinc when compared with the non-diabetics (see Table 1). Zinc concentration in diabetics was $65.22 \pm 1.13$ $\mathrm{ug} / \mathrm{dl}$ as against $85.91 \pm 2.58 \mathrm{ug} / \mathrm{dl}$ in non-diabetics. While the mean concentration of glucose in diabetics was $11.06 \pm 0.42 \mathrm{mmol} / \mathrm{l}$ the value for non-diabetics was $4.74 \pm 0.22 \mathrm{mmol} / \mathrm{l}$ (see Table 2).

It can be deduced from the above table that there is a decrease in zinc concentration in diabetic $(65.22 \pm 1.13 \mathrm{ug} / \mathrm{dl})$ compared to that of non-diabetics (85.91 $\pm 2.58 \mathrm{ug} / \mathrm{dl})$. This decrease is statistically significant $(\mathrm{p}=0.001)$.

From the table, an increase in the glucose concentration is seen in diabetics given the value $11.06 \pm 0.42 \mathrm{mmol} / \mathrm{l}$ compared to the glucose concentration in non-diabetics $4.74 \pm 0.22 \mathrm{mmol} / \mathrm{l}$. This increase is statistically significant.

\section{Discussion}

The role of zinc in cell function is multifaceted. Arising from this, whether the level of zinc is elevated or reduced there is the possibility that unusual reaction might occur. In this study we have critically examined the relationship between a raised glucose concentration in diabetics and the concentration of zinc. We observed a generalized reduction in the concentration of zinc in diabetics when compared with the concentration in non-diabetics that were randomly selected. Interestingly, the decreases in concentration among diabetics were negatively correlated with the concentration of glucose. This observation is supported by the findings of [17] and [18]. Consistent with previous reports, [19] had earlier shown that high concentration of glucose and other secretagogues decrease the islet cell labile zinc and video fluorescence analysis showed zinc concentration in the islet cells were related to the synthesis, storage and secretion of insulin. It has been established that the concentration of zinc in pancreatic beta cells is among the highest in the human body. As earlier elucidated, there is now data to show that zinc transporter (ZnT8) is required for the formation of insulin crystals in beta cells [20] [21] which to a large extent modulates the packaging efficiency of stored insulin. It is now known that epitopes of the $\mathrm{ZnT} 8$ protein are identified by autoantibodies of patients with type 1 diabetes mellitus. It has also been shown in genome wide study and independent cohort works in which a link was understood to exist between a short nucleotide polymorphism (SNP) marker within the human SLC 30A8 gene and genetic susceptibility in type 2 diabetes mellitus. Reduced zinc concentration in this study could be attributed to the 
several functions it plays. These functions have the capacity to affect the concentration.

When we consider the myriads of functions played by zinc which includes; enhancement of normal glucose homeostasis, insulin crystal formation, a transporter in the beta cell and its role in anti-oxidation defense not only acting as a co-factor of the superoxide dismutase, the fact that its rate of utilization is high presupposes that a shortfall may elicit unexpected result.

The action of zinc as a co-factor is achieved through modulating the glutathione metabolism and metallothionein expression. Zinc competes with copper and iron inhibits nicotinamide oxidative stress by causing reduction in hyperglycemia. Furthermore, zinc by its action of phosphorylation of insulin receptors enhances the transportation of glucose into the cells.

Both in vivo and in vitro studies in animals and humans have shown that zinc has numerous beneficial effects in both type 1 and 2 diabetes. Meta analysis have shown that zinc supplementation in patients with diabetes improves glycaemic control with enhancement of lipid parameters. We summarise that there is a specific range which lies between the minimum equivalent and maximum tolerable limit for the uptake of zinc to perform its myriads of roles. Over and above all, understanding the chemistry that promotes the biological activity modulating the function of zinc in diabetics will arouse further research.

\section{Conclusions}

This work has shown that a relationship exists between zinc and glucose and that there is interplay of uncommon biochemical reactions modulating the behavior of glucose in diabetics.

Inclusion of evaluation of zinc levels in attempt to diagnose diabetic condition can help elucidate the condition of diabetic patients.

\section{Acknowledgements}

We acknowledge the generosity of Geotech Medical Laboratory, Yenagoa and the Niger Delta University Laboratory where the tests were carried out having provided the needed equipment and reagents support.

\section{References}

[1] Chatterjea, M.N. and Rana, S. (2012) Metabolism of Minerals and Trace Elements in: Textbook of Medical Biochemistry. $8^{\text {th }}$ edition, Jaypee Brothers Medical Publishers (P) LTD., New Delhi, Panama City, London, 608-628.

[2] Jansen, J., Karges, W. and Rink, L. (2009) Zinc and Diabetes. Clinical Links Are Molecular Mechanisms. Journal of Nutrition Biochemistry, 20, 399-417. https://doi.org/10.1016/j.jnutbio.2009.01.009

[3] Wapnir, A.R. (1990) Protein Nutrition and Mineral Absorption. CRC Press, Boca Raton, Florida, 5.

[4] Forte, G., Bocca, B., Peruzzu, A., Tolu, F., Asara, Y., Farace, C., Oggiano, R. and Madaddu, R. (2013) Blood Metals Concentration in Type 1 and 2 Diabetics. Biolog- 
ical Trace Element Resource, 156, 79-90. https://doi.org/10.1007/s12011-013-9858-6

[5] Kazi, T.G., Afridi, H.I., Kazi, N., Tamali, M.K., Arain, M.B., Jalbani, N. and Kandhro, G.A. (2008) Copper, Chromium, Magnese, Iron, Nickel and Zinc Levels in Biological Samples of Diabetes Mellitus Patients. Biology Trace Element Resource, 122, 1-18. https://doi.org/10.1007/s12011-007-8062-y

[6] Runby, J. (2010) Zinc, Zinc Transporters and Diabetes. Diabetologia, 53, 1549-1551. https://doi.org/10.1007/s00125-010-1793-X

[7] Brender, J.R., Hartman, K., Nonga, R.P., Popvych, N., Dela Salud, B.R., Vivekanandan, S., Marsh, E.N. and Rmamoothy, A. (2010) Role of Zinc in Human Islet Amyloid Pophypeptide Aggregagtion. Journal of American Chemical Society, 132, 8973-8983. https://doi.org/10.1021/ja1007867

[8] Wijese, K.N., Dai, F.F., Hardy, A.B., Giglou, P.R., Bhattacharjee, A., Koshkin, V., Chimienti, F., Gaisano, H.Y., Rutter, G.A. and Wheeler, B.B. (2010) Beta Cell Specific ZnT8 Deletion in Mice Causes Marked Defects in Insulin Processing Crystallization and Secretion. Diabetologia, 53, 1656-1668.

https://doi.org/10.1007/s00125-010-1733-9

[9] Carl, A.B., Edward, R. anf David, E.B. (2008) Carbohydrates in: Tiez Fundamentals of Clinical Chemistry. $6^{\text {th }}$ Edition, Saunders, Elsevier Inc., New Delhi, 505-507.

[10] Arthur (2013) Zinc, Insulin as Diabetes. Journal of the American College of Nutrition, 17, 109-115.

[11] Dodson, G. and Steiner, D. (1998) The Role of Assembly in Insulin Biosynthesis. Current Opinion Structure Biological, 8, 189-194.

[12] Simeon, S.F. and Taylor, C.G. (2001) Dietary Zinc Supplementation Attenuates Hyperglycemia in d/b/db Mice. EVP Biological Medicine (Mary Wood), 226, 43-51.

[13] Faure, P., Benhamou, P.Y., Perard, A., Halimi, S. and Rousel, A.M. (1995) Lipid Perioxidation in Insulin. Dependent Diabetic Patients with Early Retina Degenerative Lesions: Effects of an Oral Zinc Supplementation. Journal of Clinical Nutrition, 49, 282-288.

[14] Swardfager (2013) Potential Role of Zinc in the Pathophysiology and Treatment of Major Depressive Disorder. Neuroscience \& Biobehavioral Reviews, 377, 911-929.

[15] Tayawardena, R., Ranasinghe, P., Galapathy, P., Malkanthi, R., Constantine, G. and Katulanda, P. (2012) Effect of Zinc Supplementation on Diabetes Mellitus: A Systematic Review and Meta-Analysis. Diabetologia Metabolic Syndrome, 4, 13. https://doi.org/10.1186/1758-5996-4-13

[16] Yang, V.L. (2014) Zinc and Insulin in Pancreatic Beta-Cells. Endocrine, 45, 178-189. https://doi.org/10.1007/s12020-013-0032-x

[17] Zalewski, P.D., Millard, S.H. and Forbes, I.J. (1994) Video Image Analysis of Labile Zinc in Viable Pancreatic Islet Cells using a Specific Florescent Probe for Zinc. Journal of Histochemistry \& Cytochemistry, 42, 877-884. https://doi.org/10.1177/42.7.8014471

[18] Migo, X., Sun, W., Fu, Y., Mia, O.L. and Cai, L. (2013) Zinc Homeostasis in the Metabolic Syndrome and Diabetes. Frontiers in Medicine, 7, 31-52. https://doi.org/10.1007/s11684-013-0251-9

[19] Capdor, J., Forster, M., Petocz, P. and Samman, S. (2013) Zinc and Glycemic Control: A Meta Analysis of Randomized Placebo Controlled Supplementation Trials in Human. Journal of Trace Elements in Medicine and Biology, 27, 137-142. https://doi.org/10.1016/j.jtemb.2012.08.001

[20] Ruz, M., Carrasco, F., Rojas, P., Codoceo, J., Inostroza, J., Basti-fer, K., Valencia, A., 
Vasquez, K., Galgami, J. and Pere, A. (2013) Zinc as a Potential Coadjuvant in Therapy for Type 2 Diabetes. Food and Nutrition Bulletin, 34, 215-221.

https://doi.org/10.1177/156482651303400210

[21] Carocho, M. and Ferreira, I.C. (2013) A Review on Antioxidants, Prooxidants, and Related Controversy: Natural and Synthetic Compounds, Screening and Analysis Methodologies and Future Perspectives. Food and Chemical Toxicology, 15, 51-25. 